\title{
A Review of Covid-19 Vaccines: What needs to be known and its expected effect on the human population?
}

\author{
Syahrul Tuba $^{*}$, Widyati ${ }^{1}$, Syed Azhar Syed Sulaiman ${ }^{2}$ \\ ${ }^{1}$ Department of Clinical Pharmacy, Faculty of Military Pharmacy, Indonesia Defence \\ University, Sentul, 16810, Indonesia \\ ${ }^{2}$ Direktur Advanced Medical and Dental Institute, Universiti Sains Malaysia, Pulau Pinang, \\ 13200, Malaysia \\ *Corresponding author; syahrul.tuba@idu.ac.id
}

\begin{abstract}
The COVID-19 pandemic is a devastating blow to the entire world community and changes the order of human life. All efforts and strategies are being carried out to contain and reduce the spread of the SARS-COV-2 virus, both by tightening the health protocol and using vaccines to the public. Currently, several vaccines are available and have passed phase 3 clinical trials, such as vector vaccines (Gamaleya Sputnik V Russia, University of Oxford/AstraZeneca, CanSino, and Janssen Pharmaceutical Companies), mRNA-based vaccines (Moderna/BioNTech/Fosun Pharma/Pfizer), inactivated vaccines (SinoVac and SinoPharm from China, Covaxin from Bharat Biotech India), and adjuvanted recombinant protein nanoparticles (Novavax from the USA) are expected to be able to suppress the spread of the virus and produce a minimum of 70 percent herd-immunity in a population. Each vaccine's efficacy varies from the lowest, namely the Sinovac vaccine (CoronaVac) 50\% to the highest the Novavax vaccine (NVX-Cov2373) 96\% effectivity value. Moreover, further rigorous research is still being carried out for the development of an effective and efficient vaccine.
\end{abstract}

Keywords; Vaccine Development; Clinical Trial; COVID-19; SARS-COV-2

\section{INTRODUCTION}

Implementation of control measures and protocol health in life are crucially required, such as using masks, physical distancing, testing of persons exposed to or symptomatic, contact tracing and isolation have helped to limit the contagion that has been applied strictly, but such measures have been applied varied and proven yet sufficient in inhibiting the spread of the coronavirus disease 2019 (COVID-19) (Baden et al., 2021).

The vaccination technique is an attractive and powerful medical approach for dominant the severe acute respiratory syndrome coronavirus type 2, preventing the spread, and protecting those who are at high risk of infection (Baden et al., 2021). The process of vaccination has taken place in all countries including Indonesia and Malaysia. Vaccination is anticipated to provide a herd-immunity a minimum of $70 \%$ of the population and 80 percent without used other intervention for instance physical distancing (Bartsch et al., 2020).

Based on the evaluation of patients with positive SARS-COV-2 revealed that antibody binder and main bidders targeting the receptor-binding domain subunit S1 (Spike 1) (Premkumar et al., 2020). The main challenge when making vaccines is how effectively the vaccine can generate an immune response in the human body. Characteristics response such immune is the formation of neutralizing antibodies, formation of T-cell responses, and prevention of disease 
following immunization (response induced by the vaccine causes an increase in severity of disease) (Tseng et al., 2012). At present, the dominant circulating variant of spike protein mutations of the virus from Britain (B.1.1.7, deletion 69-70, deletion 144, N501Y, A570D, D614G, P681H, T716I, S982A, D1118H, and there are mutations in other genomic regions as well), South Africa (B.1.351) and Brazil (P.1) are facilitating rapid viral spread (Ecdc, 2020; Faria et al., 2021; Tegally et al., 2020) that may interfere effectivity of vaccine program.

There are enormous direct the development of the vaccine candidates to prevent transmission of COVID-19 consist of 84 trials that are still in clinical assessment (15 of them have been in phase 3 and 5 vaccines under phase 4 clinical trials) and 184 in preclinical analysis with different route of administration, doses, and schedule (Table 1) (WHO, 2021). Some vaccines that are currently and have passed phase 3 clinical trials are vector vaccines (Gamaleya National Research Center for Epidemiology and Microbiology, University of Oxford/AstraZeneca, CanSino Biological Inc/Beijing Institute of Biotechnology, and Janssen Pharmaceutical Companies), mRNA -based vaccines, (Moderna/National Institute of Allergy and Infectious Diseases and BioNTech/Fosun Pharma/Pfizer), inactivated vaccines (SinoVac, Wuhan Institute of Biological Products/Sinopharm, Beijing Institute of Biological Products/Sinopharm, and Bharat Biotech), and adjuvanted recombinant protein nanoparticles (Novavax) (Baden et al., 2021; Logunov et al., 2021; Polack et al., 2020; Voysey et al., 2021).

Table 1. Number of Doses, Intervals, and Route of Administration of Vaccine Candidates (WHO, 2021)

\begin{tabular}{cc}
\hline Doses and Interval & Vaccine in Development \\
\hline $\mathbf{1}$ dose; & $\mathbf{1 3}$ \\
Day o & 13 \\
$\mathbf{2}$ doses; & $\mathbf{5 1}$ \\
Day o +14 & 6 \\
Day o +21 & 19 \\
Day o + 28 & 26 \\
$\mathbf{3}$ doses; & $\mathbf{1}$ \\
Day o + 28+56 & 1 \\
\hline Administration & $\mathbf{2}$ \\
\hline Oral Injection; & $\mathbf{6 9}$ \\
SC/Sub-Cutaneous & 3 \\
ID/Intra-Dermal & 3 \\
IM/Intra-Muscular & 63
\end{tabular}

Based on the preceding description, this review presents of vaccine development with different types (Table 3) that was provided by pharma industry to combat and eliminate spreading of SARS-COV-2 in a population. Moreover, it develops herd-immunity at least $70 \%$ in the community.

\section{METHOD}

The review was conducted using the google engine to find the precise literature references (Scopus, PubMed, Medline, WHO Website). The key search terms 'Vaccine Development', 'Clinical Trial', 'COVID-19', 'SARS-COV-2'. The range of period for searching the references for this review's study is 4 November 2020 to 29 March 2021. 


\section{RESULT AND DISCUSSION}

\section{mRNA Vaccine}

In clinical trials, mRNA-based vaccines were found to be more than $90 \%$ effective against SARS-COV-2 such as Moderna/BioNTech/Fosun Pharma/Pfizer. This high effectiveness of the vaccine is associated with few/rare side effects, despite the local and systemic reactogenicity to the mRNA vaccine. The advantages of mRNA vaccines are the speed of vaccine production (only a few weeks) and the ability to generate a $T_{H} 2$ and $T_{H} 1$ response (Table 2) (Creech et al., 2021).

Table 2. Advantages and Disadvantages of Vaccine Development Methods (Kaur \& Gupta, 2020; Zhang et al., 2019)

\begin{tabular}{clll}
\hline Vaccine & \multicolumn{2}{c}{ Advantages } & \multicolumn{2}{c}{ Disadvantages } \\
\hline Viral vector & $\begin{array}{l}\text { Highly an innate immune response, Induction of anti-vector } \\
\text { induction of } \mathrm{T} \text { cell immune responses } \\
\text { and cell B. Widely used for MESR-COV. }\end{array}$ & $\begin{array}{l}\text { manufacturing. Integrating } \\
\text { into the host genome that } \\
\text { induce cancer. }\end{array}$
\end{tabular}

DNA vaccine Not contagious; shortly stimulation of the innate immune response; free cell and egg; stable, fast, and scalable production; clicking the induction of $\mathrm{T}$ cell immune response and $\mathrm{B}$.

Potential for integration into the human genome; low immunogenicity in humans, induce the synthesis of anti-immunoglobulins.

RNA vaccine Degradation is naturally in the body, not contagious, not integrate into the human Potential for instability, genome, non-cell egg virus, fast, and reactogenicity reported scalable production; shortly stimulation of the innate immune response; clicking the induction of $\mathrm{T}$ cell immune responses and cell B.

\section{Virus Vector Vaccines}

Currently, about 25 research groups are working on a viral vector vaccine. Viruses like rubeola or animal virus are genetically designed in order that they will turn out coronavirus proteins within the body. There are 2 types: people who will still replicate at in cells and people that cannot because of a key gene has been deactivated (Callaway, 2020). The use of adenovirus vaccine has been used in the USA and Europe, two vaccines have shown promising initial results, namely the Serotype 26 adenovirus vector vaccine (Ad26.CoV2. S; Johnson \& Johnson) and the ChAdOx of Chimpanzee adenovirus vector vaccine (AstraZeneca) (Creech et al., 2021). Both vaccines have efficacy in preventing hospitalization and death of COVID19 patients, but they are still not maximal in preventing diseases caused by the new variant SARS-CoV-2 (Creech et al., 2021). The Sputnik V vaccine (Gam-COVID-Vac) uses a combination of the rAd type 26 (rAd26) and rAd type 5 (rAd5), rAd26-S, and rAd5-S vaccine vectors given separately intramuscularly at 21-day intervals (table 1). Gam-COVID-Vac has a 91.6\% efficacy of preventing infection COVID-19 (Logunov et al., 2021). 


\section{The Vaccine Inactivated and Subunit Vaccine Proteins}

Inactivated or killed vaccines made from cultured and then chemically inactivated viruses are one path to vaccine production, which can produce native antigenic epitopes (binding to $\mathrm{T}$ cell and B cell antibodies) expressed in a stable and conformational manner (Delrue et al., 2012). One approach that is used in the production of vaccines from the killed virus is UV-inactivated conducted on laboratory Biosafety Level 3 (BSL3), which includes the step of expansion, titration, inactivated, and ultracentrifuge the virus (Lundstrom, 2020). Sinopharm and Sinovac are two of the companies working on this form of vaccine, which has been tested in a phase 3 trial and received international approval for use as a COVID-19 vaccine. (Creech et al., 2021).

Bharat Biotech (BBV152/Covaxin) from the Indian vaccine industry, has succeeded in making a vaccine derived from the intact virion of the SARS-COV-2 virus that has been killed (inactivated virus). Based on phase 3 clinical trials the Covaxin vaccine showed high clinical efficacy $(81 \%)$ against COVID-19, as well as high immunogenicity against some of the variants (Ella et al., 2021). The presence of the additive/adjuvant Algel-IMDG can increase the immune response of T cells to COVID-19, which leads to long-term protection ( $\mathrm{Li} \& \mathrm{Zhu}$, 2021).

Protein $\mathrm{S}$ as a recombinant protein subunit is another approach to vaccine development. This method may protect immunized animals in vitro, but it has the potential to produce a polarized immune response (Zimmermann \& Curtis, 2019). Example of vaccines using this method is Novavax, using adjuvant Matrix-M-based saponin, which has efficacy $89.3 \%$ of patients COVID 19 through clinical trials phase 3 in the UK (Callaway \& Mallapaty, 2021). Currently, more than $60 \%$ of vaccine development uses the protein subunit approach, even though none has the status as an emergency use authorization (Creech et al., 2021).

Table 3. Types of Vaccines Circulating in Various Countries

\begin{tabular}{|c|c|c|c|c|c|}
\hline Vaccine & Mechanism & Efficacy & Dose & Storage & $\begin{array}{l}\text { Country } \\
\text { of Origin }\end{array}$ \\
\hline $\begin{array}{l}\text { Moderna } \\
\text { (mRNA- } \\
1273 \text { ) }\end{array}$ & $\begin{array}{l}\text { mRNA Vaccine } \\
\text { Encapsulated. } \\
\text { The mRNA } \\
\text { encoding against } \\
\text { the protein spike is } \\
\text { protected in lipid } \\
\text { nanoparticles } \\
\text { (such as soap } \\
\text { bubbles). Once } \\
\text { absorbed, cells } \\
\text { express spike } \\
\text { protein resulting } \\
\text { in immune } \\
\text { response } \\
\text { (immunogenicity) }\end{array}$ & $\begin{array}{l}94 \% \\
\text { (original } \\
\text { strain) }\end{array}$ & $\begin{array}{l}0.5 \mathrm{ml} \\
\text { divided } \\
\text { into } 2 \\
\text { doses, } \\
\text { each } \\
\text { dose for } \\
28 \\
\text { days. }\end{array}$ & $\begin{array}{l}-20^{\circ} \mathrm{C}=6 \\
\text { months } \\
2-8{ }^{\circ} \mathrm{C}=30 \\
\text { days }\end{array}$ & $\begin{array}{l}\text { USA (Baden } \\
\text { et al., 2021) }\end{array}$ \\
\hline $\begin{array}{l}\text { BioNTech/Pf } \\
\text { izer } \\
(\mathrm{BNT} 162 \mathrm{~b} 2)\end{array}$ & $\begin{array}{l}\text { mRNA Vaccine } \\
\text { Encapsulated. } \\
\text { The mRNA } \\
\text { encoding the } \\
\text { protein spike is }\end{array}$ & $\begin{array}{l}95 \% \\
\text { (original } \\
\text { strain) }\end{array}$ & $\begin{array}{l}0.3 \mathrm{ml} \\
\text { divided } \\
\text { into } 2 \\
\text { doses, } \\
\text { each }\end{array}$ & $\begin{array}{l}-70{ }^{\circ} \mathrm{C}=6 \\
\text { months } \\
2-8{ }^{\circ} \mathrm{C}=5 \\
\text { days }\end{array}$ & $\begin{array}{l}\text { USA and } \\
\text { Germany } \\
\text { (Polack et al., } \\
\text { 2020) }\end{array}$ \\
\hline
\end{tabular}


protected in the lipid nanoparticles (such as soap bubbles). Once absorbed, cells express spike protein resulting in immune response (immunogenicity)

Oxford/Astra (ChAdOx1/A ZD1222 [Covishield])

Johnson \& Virus

Johnson (JNJ Vector Vaccines 78436735 / The dsDNA Ad26.COV2. encoding against S) the spike protein is protected in the virus. Infected cells express the spike protein resulting in immune response (immunogenicity)

\section{Gamaleya Virus}

(Sputnik V / Vector Vaccines

Gam-Covid- The dsDNA $\mathrm{Vac})$ encoding against the spike protein is protected in the virus. Infected cells express the spike protein resulting in immune response (immunogenicity) dose for

21

days.

$82 \% 2$ doses, $2-8{ }^{\circ} \mathrm{C}=6$ English +

(original intermit months Swedish (Vo strain), tent ysey et al., $\begin{array}{lll}10 \% & \text { each }\end{array}$

(South dose 12

African weeks

variant

B1351)

\section{$72 \%$}

(USA str
1 dose $2-8{ }^{\circ} \mathrm{C}=3$
months
$-20{ }^{\circ} \mathrm{C}=2$
years

USA (Sadoff

et al., 2021)

ain),

$57 \%$

(South

African

variant

B1351)

$\begin{array}{llll}91.6 \% & 0.5 \mathrm{ml} & 2-8{ }^{\circ} \mathrm{C}=6 & \text { Russia (Logu } \\ \text { (original } & \text { in } 2 & \text { months, } & \text { nov et al., } \\ \text { strain) } & \text { doses, } & -20{ }^{\circ} \mathrm{C}=2 & 2021) \\ & \text { each } & \text { years } \\ & \text { dose for } & & \\ & \text { 21 days } & & \\ & \end{array}$




\begin{tabular}{|c|c|c|c|c|c|}
\hline $\begin{array}{l}\text { Novavax } \\
\text { (NVX- } \\
\text { Cov2373) }\end{array}$ & $\begin{array}{l}\text { Vaccine particles } \\
\text { that resemble } \\
\text { viruses } \\
\text { The nanoparticles } \\
\text { are covered by a } \\
\text { synthetic material } \\
\text { called Spike } \\
\text { protein. Has } \\
\text { additional } \\
\text { ingredients called } \\
\text { adjuvants to } \\
\text { increase immune } \\
\text { reactions } \\
\text { (immunogenicity) }\end{array}$ & $\begin{array}{l}96 \% \\
\text { (original } \\
\text { strain), } \\
86 \% \\
\text { (B117 } \\
\text { UK } \\
\text { variant), } \\
55 \% \\
\text { (B1351 } \\
\text { South } \\
\text { African } \\
\text { variant) }\end{array}$ & $\begin{array}{l}2 \text { doses, } \\
\text { break } \\
\text { each } \\
\text { dose } 21 \\
\text { days }\end{array}$ & $\begin{array}{l}2-8^{\circ} \mathrm{C}=6 \\
\text { months } \\
-20{ }^{\circ} \mathrm{C}=2 \\
\text { years }\end{array}$ & $\begin{array}{l}\text { USA (Callaw } \\
\text { ay \& } \\
\text { Mallapaty, } \\
\text { 2021) }\end{array}$ \\
\hline $\begin{array}{l}\text { Sinopharm } \\
\text { (BBIBP- } \\
\text { CorV) }\end{array}$ & $\begin{array}{l}\text { Vaccine inactivat } \\
\text { ed, } \\
\text { SARS-COV-2 } \\
\text { chemically } \\
\text { inactive (with a } \\
\text { chemical called } \\
\text { beta- } \\
\text { propiolactone) so } \\
\text { it cannot replicate } \\
\text { but all the protein } \\
\text { remains intact. }\end{array}$ & $\begin{array}{l}79 \% \\
\text { (original } \\
\text { strain) }\end{array}$ & $\begin{array}{l}2 \text { doses, } \\
\text { break } \\
\text { each do } \\
\text { se } 21 \\
\text { days }\end{array}$ & $2-8{ }^{\circ} \mathrm{C}$ & $\begin{array}{l}\text { China (Xia et } \\
\text { al., 2021) }\end{array}$ \\
\hline $\begin{array}{l}\text { Sinovac } \\
(\text { CoronaVac) }\end{array}$ & $\begin{array}{l}\text { Vaccine is inactiv } \\
\text { ated, } \\
\text { SARS-COV-2 } \\
\text { chemically } \\
\text { inactive (with a } \\
\text { chemical called } \\
\text { beta- } \\
\text { propiolactone) so } \\
\text { it cannot replicate } \\
\text { but all the protein } \\
\text { remains intact. }\end{array}$ & $\begin{array}{l}50 \% \\
\text { (original } \\
\text { strain) }\end{array}$ & $\begin{array}{l}2 \text { doses } \\
\text { break } \\
\text { each } \\
\text { dose for } \\
14 \\
\text { days. }\end{array}$ & $2-8{ }^{\circ} \mathrm{C}$ & $\begin{array}{l}\text { China (Gao et } \\
\text { al., 2020) }\end{array}$ \\
\hline $\begin{array}{l}\text { Bharat } \\
\text { Biotech } \\
\text { (BBV152/ } \\
\text { Covaxin) }\end{array}$ & $\begin{array}{l}\text { Vaccine is } \\
\text { inactivated, } \\
\text { SARS-COV-2 } \\
\text { chemically } \\
\text { inactive (with a } \\
\text { chemical called } \\
\text { beta- } \\
\text { propiolactone) so } \\
\text { it cannot replicate } \\
\text { but all the protein } \\
\text { remains intact. }\end{array}$ & $\begin{array}{l}81 \% \\
\text { (original } \\
\text { strain) }\end{array}$ & $\begin{array}{l}2 \text { doses } \\
\text { break } \\
\text { each } \\
\text { dose } 28 \\
\text { days. }\end{array}$ & $2-8^{\circ} \mathrm{C}$ & $\begin{array}{l}\text { India (Ella et } \\
\text { al., 2021) }\end{array}$ \\
\hline
\end{tabular}




\section{CONCLUSION}

Various vaccines were produced around the world to provide better control of covid-19 pandemic. Due to differences in how the vaccines was developed, it created numerous issues especially related to efficacy and side effects. This article helps to clarify some of the questions regarding the vaccines and its sources of production, the doses and storage form.

Health workers are the last bastion in handling COVID-19 patients. The process of preventing and minimizing the spread of COVID-19 is the main goal of the current vaccination. The presence of several types of vaccines at this time is expected to be able to provide strategic solutions to overcome the pandemic situation that has hit various countries in the world. The implementation of the vaccination program is expected to produce a herd-immunity of at least $70 \%$ in a population so that they can quickly get out of the pandemic and live normally as before. One of the factors that can affect the effectiveness of vaccines is the presence of virus mutations, so that further research on the effectiveness of viral genetic mutations is still huge necessary.

\section{ACKNOWLEDGMENT}

I would like to thank the colleagues of Faculty of Military Pharmacy, Indonesia Defense University and Advanced Medical and Dental Institute, Universiti Sains Malaysia for technical supports on this research.

\section{CONFLICT OF INTEREST}

There is no conflict of interest in this study.

\section{REFERENCES}

WHO, Draft landscape of COVID-19 candidate vaccines. https://www.who.int/publications/m/item/draft-landscape-of-covid-19-candidatevaccines. Date: Jan 22, 2021. Date accessed: March 04, 2021.

Baden, L. R., el Sahly, H. M., Essink, B., Kotloff, K., Frey, S., Novak, R., Diemert, D., Spector, S. A., Rouphael, N., Creech, C. B., McGettigan, J., Khetan, S., Segall, N., Solis, J., Brosz, A., Fierro, C., Schwartz, H., Neuzil, K., Corey, L., ... Zaks, T. (2021). Efficacy and Safety of the mRNA-1273 SARS-CoV-2 Vaccine. New England Journal of Medicine, 384(5), 403-416. https://doi.org/10.1056/nejmoa2035389

Bartsch, S. M., O’Shea, K. J., Ferguson, M. C., Bottazzi, M. E., Wedlock, P. T., Strych, U., McKinnell, J. A., Siegmund, S. S., Cox, S. N., Hotez, P. J., \& Lee, B. Y. (2020). Vaccine Efficacy Needed for a COVID-19 Coronavirus Vaccine to Prevent or Stop an Epidemic as the Sole Intervention. American Journal of Preventive Medicine, 59(4), 493-503. https://doi.org/10.1016/j.amepre.2020.06.011

Callaway, E. (2020). The race for coronavirus vaccines: a graphical guide. Nature, 580(7805), 576-577. https://doi.org/10.1038/d41586-020-01221-y

Callaway, E., \& Mallapaty, S. (2021). Novavax offers first evidence that COVID vaccines protect people against variants. Nature, 590(7844), 17. https://doi.org/10.1038/d41586021-00268-9 
Creech, C. B., Walker, S. C., \& Samuels, R. J. (2021). SARS-CoV-2 Vaccines. JAMA. https://doi.org/10.1001/jama.2021.3199

Delrue, I., Verzele, D., Madder, A., \& Nauwynck, H. J. (2012). Inactivated virus vaccines from chemistry to prophylaxis: Merits, risks and challenges. In Expert Review of Vaccines (Vol. 11, Issue 6, pp. 695-719). https://doi.org/10.1586/erv.12.38

Ecdc. (2020). Suggested citation: European Centre for Disease Prevention and Control. Rapid increase of a SARS-CoV-2 variant with multiple spike protein mutations observed in the Rapid increase of a SARS-CoV-2 variant with multiple spike protein mutations observed in the United Kingdom. http://covid19-countryoverviews.ecdc.europa.eu/\#34_United_Kingdom

Ella, R., Vadrevu, K. M., Jogdand, H., Prasad, S., Reddy, S., Sarangi, V., Ganneru, B., Sapkal, G., Yadav, P., Abraham, P., Panda, S., Gupta, N., Reddy, P., Verma, S., Kumar Rai, S., Singh, C., Redkar, S. V., Gillurkar, C. S., Kushwaha, J. S., ... Bhargava, B. (2021). Safety and immunogenicity of an inactivated SARS-CoV-2 vaccine, BBV152: a double-blind, randomised, phase 1 trial. The Lancet Infectious Diseases. https://doi.org/10.1016/s1473-3099(20)30942-7

Faria, N. R., Mellan, T. A., Whittaker, C., Claro, I. M., Candido, D. da S., Mishra, S., Crispim, M. A. E., Sales, F. C., Hawryluk, I., McCrone, J. T., Hulswit, R. J. G., Franco, L. A. M., Ramundo, M. S., de Jesus, J. G., Andrade, P. S., Coletti, T. M., Ferreira, G. M., Silva, C. A. M., Manuli, E. R., ... Sabino, E. C. (2021). Genomics and epidemiology of a novel SARS-CoV-2 lineage in Manaus, Brazil. MedRxiv: The Preprint Server for Health Sciences. https://doi.org/10.1101/2021.02.26.21252554

Gao, Q., Bao, L., Mao, H., Wang, L., Xu, K., Yang, M., Li, Y., Zhu, L., Wang, N., Lv, Z., Gao, H., Ge, X., Kan, B., Hu, Y., Liu, J., Cai, F., Jiang, D., Yin, Y., Qin, C., ... Qin, C. (2020). Development of an inactivated vaccine candidate for SARS-CoV-2. Science, 369(6499), 77-81. https://doi.org/10.1126/science.abc1932

Kaur, S. P., \& Gupta, V. (2020). COVID-19 Vaccine: A comprehensive status report. In Virus Research (Vol. 288). Elsevier B.V. https://doi.org/10.1016/j.virusres.2020.198114

Li, J.-X., \& Zhu, F.-C. (2021). Adjuvantation helps to optimise COVID-19 vaccine candidate. The Lancet. Infectious Diseases. https://doi.org/10.1016/S14733099(21)00094-3

Logunov, D. Y., Dolzhikova, I. v, Shcheblyakov, D. v, Tukhvatulin, A. I., Zubkova, O. v, Dzharullaeva, A. S., Kovyrshina, A. v, Lubenets, N. L., Grousova, D. M., Erokhova, A. S., Botikov, A. G., Izhaeva, F. M., Popova, O., Ozharovskaya, T. A., Esmagambetov, I. B., Favorskaya, I. A., Zrelkin, D. I., Voronina, D. v, Shcherbinin, D. N., ... Gintsburg, A. L. (2021). Safety and efficacy of an rAd26 and rAd5 vector-based heterologous prime-boost COVID-19 vaccine: an interim analysis of a randomised controlled phase 3 trial in Russia. The Lancet. https://doi.org/10.1016/s0140-6736(21)00234-8

Lundstrom, K. (2020). The Current Status of COVID-19 Vaccines. Frontiers in Genome Editing, 2. https://doi.org/10.3389/fgeed.2020.579297 
Polack, F. P., Thomas, S. J., Kitchin, N., Absalon, J., Gurtman, A., Lockhart, S., Perez, J. L., Pérez Marc, G., Moreira, E. D., Zerbini, C., Bailey, R., Swanson, K. A., Roychoudhury, S., Koury, K., Li, P., Kalina, W. v., Cooper, D., Frenck, R. W., Hammitt, L. L., ... Gruber, W. C. (2020). Safety and Efficacy of the BNT162b2 mRNA Covid-19 Vaccine. New England Journal of Medicine, 383(27), 2603-2615.

https://doi.org/10.1056/nejmoa2034577

Premkumar, L., Segovia-Chumbez, B., Jadi, R., Martinez, D. R., Raut, R., Markmann, A. J., Cornaby, C., Bartelt, L., Weiss, S., Park, Y., Edwards, C. E., Weimer, E., Scherer, E. M., Rouphael, N., Edupuganti, S., Weiskopf, D., Tse, L. v., Hou, Y. J., Margolis, D., ... de Silva, A. M. (2020). The receptor-binding domain of the viral spike protein is an immunodominant and highly specific target of antibodies in SARS-CoV-2 patients. Science Immunology, 5(48). https://doi.org/10.1126/SCIIMMUNOL.ABC8413

Sadoff, J., le Gars, M., Shukarev, G., Heerwegh, D., Truyers, C., de Groot, A. M., Stoop, J., Tete, S., van Damme, W., Leroux-Roels, I., Berghmans, P.-J., Kimmel, M., van Damme, P., de Hoon, J., Smith, W., Stephenson, K. E., de Rosa, S. C., Cohen, K. W., McElrath, M. J., ... Schuitemaker, H. (2021). Interim Results of a Phase 1-2a Trial of Ad26.COV2. S Covid-19 Vaccine. New England Journal of Medicine. https://doi.org/10.1056/nejmoa2034201

Tegally, H., Wilkinson, E., Giovanetti, M., Iranzadeh, A., Fonseca, V., Giandhari, J., Doolabh, D., Pillay, S., San, E. J., Msomi, N., Mlisana, K., von Gottberg, A., Walaza, S., Allam, M., Ismail, A., Mohale, T., Glass, A. J., Engelbrecht, S., van Zyl, G., ... de Oliveira, T. (2020). Emergence and rapid spread of a new severe acute respiratory syndrome-related coronavirus 2 (SARS-CoV-2) lineage with multiple spike mutations in South Africa. In medRxiv. medRxiv. https://doi.org/10.1101/2020.12.21.20248640

Tseng, C. te, Sbrana, E., Iwata-Yoshikawa, N., Newman, P. C., Garron, T., Atmar, R. L., Peters, C. J., \& Couch, R. B. (2012). Immunization with SARS coronavirus vaccines leads to pulmonary immunopathology on challenge with the SARS virus. PLoS ONE, 7(4). https://doi.org/10.1371/journal.pone.0035421

Voysey, M., Clemens, S. A. C., Madhi, S. A., Weckx, L. Y., Folegatti, P. M., Aley, P. K., Angus, B., Baillie, V. L., Barnabas, S. L., Bhorat, Q. E., Bibi, S., Briner, C., Cicconi, P., Collins, A. M., Colin-Jones, R., Cutland, C. L., Darton, T. C., Dheda, K., Duncan, C. J. A., ... Zuidewind, P. (2021). Safety and efficacy of the ChAdOx1 nCoV-19 vaccine (AZD1222) against SARS-CoV-2: an interim analysis of four randomised controlled trials in Brazil, South Africa, and the UK. The Lancet, 397(10269), 99-111. https://doi.org/10.1016/S0140-6736(20)32661-1

Xia, S., Zhang, Y., Wang, Y., Wang, H., Yang, Y., Gao, G. F., Tan, W., Wu, G., Xu, M., Lou, Z., Huang, W., Xu, W., Huang, B., Wang, H., Wang, W., Zhang, W., Li, N., Xie, Z., Ding, L., ... Yang, X. (2021). Safety and immunogenicity of an inactivated SARSCoV-2 vaccine, BBIBP-CorV: a randomised, double-blind, placebo-controlled, phase 1/2 trial. The Lancet Infectious Diseases, 21(1), 39-51. https://doi.org/10.1016/S14733099(20)30831-8 
Zhang, C., Maruggi, G., Shan, H., \& Li, J. (2019). Advances in mRNA vaccines for infectious diseases. In Frontiers in Immunology (Vol. 10, Issue MAR). Frontiers Media S.A. https://doi.org/10.3389/fimmu.2019.00594

Zimmermann, P., \& Curtis, N. (2019). Factors that influence the immune response to vaccination. In Clinical Microbiology Reviews (Vol. 32, Issue 2). American Society for Microbiology. https://doi.org/10.1128/CMR.00084-18 